\title{
WRITING CONTROL PROGRAMS FOR COMPUTER NUMERAL CONTROL MACHINES
}

Azamjon Tokhirov

Trainee teacher,

Department Automation of mechanical engineering, Andijan machie-building institute

Uzbekistan, Andijan

E-mail: azamjonmagistr1991@gmail.com

\section{НАПИСАНИЕ ПРОГРАММ УПРАВЛЕНИЯ ДЛЯ КОМПЬЮТЕРНЫХ ЧИСЛОВЫХ УПРАВЛЯЮЩИХ МАШИН}

Тохиров Азамжон Иброхим угли

учитель-стажер,

Андижанский матиностроительный институт кафедра автоматизаиии машиностроения, Узбекистан, г. Андижан

\begin{abstract}
This article discusses methods for creating a program for processing parts on computer numeral control machines used in mechanical engineering and manufacturing enterprises.

\section{АННОТАЦИЯ}

В статье рассмотрены методы создания программы обработки деталей на станках с числовым программным управлением, применяемых в машиностроении и производственных предприятиях.

Keywords: CNC, Software, programming, G-code, design, technology, CAD, CAM, CAE

Ключевые слова: ЧПУ, программное обеспечение, программирование, G-код, дизайн, технологии, CAD, CAM, CAE.
\end{abstract}

\section{Introduction}

Today, all industries are at the peak of their development. Digitalization is also taking place in the field of mechanical engineering. Digital software-controlled (RDB) machines are now being used in production instead of the usual conventional machines. The production process is carried out on automatic lines.

\section{Methodology}

RDB devices can be thought of as a system of 3 blocks: a control program (a device for reading it); RDB devices and the machine itself.

On RDB machines, the processing of details is done by creating a machining program. There are three methods of programming for RDB machines:

- Manual programming;

- Programming on the control panel of the RDB machine;

- Programming with CAD / CAM system.

\section{Manual programming.}

Manual programming is the creation of a management program by a programmer without the use of special software based on knowledge of these commands.
Hence, it is clear that this programming method is the most time consuming, it is used to create a simple detail processing management program.

Manual programming consists of the following steps:

- preparation of technological information;

- calculation and analysis;

- coding;

- recording the program;

- Adjustment and preparation for production.

\section{Discussion}

The most time-consuming phase is the program development and implementation phase, which accounts for $30 \%$ of the programming time [6-10]. The first stage (preparation of technological data) is integral to any programming method. At the stage of technological preparation of the control program, the development of operational technology, selection of tools, selection of the working sequence and sequence of technological transitions, selection of cutting rhythms, etc. are carried out.

The computational and analytical phase consists of determining the coordinates of the trajectory points of the intersecting instruments, e.g., intersection points, the attempt of straight lines by an arc, and so on. Technological points are needed to change the cutting tools, as 
well as to change the processing modes (amount of thrust, spindle speed, etc.)

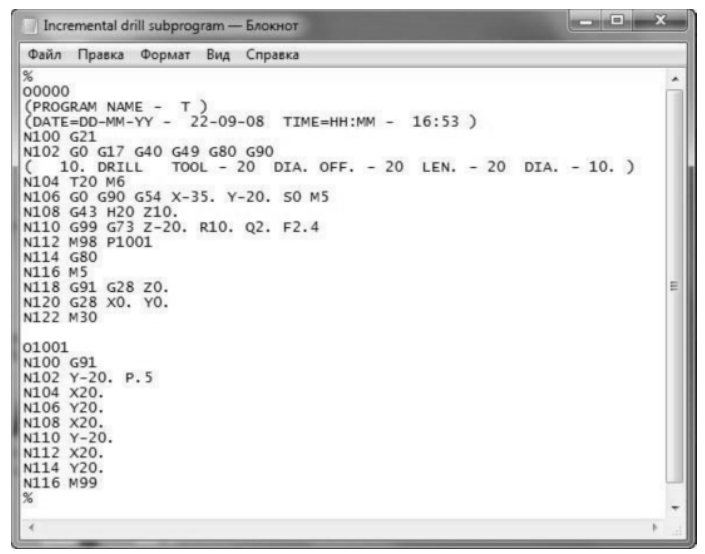

Figure 1. A program designed to process a detail on an RDB machine

\section{Results}

Processing in RDB is usually programmed in a language called ISO 7 bit language or $\mathrm{G}$ and $\mathrm{M}$ code language. The $\mathrm{G}$ and $\mathrm{M}$ code languages are based on the rules of the International Organization for Standardization (ISO) and the Electronic Industry Association (ESA).

\section{Advantages:}

- Almost unlimited possibilities in software development.

- Allows you to change any process parameters (for example, cutting speed, cutting depth, thrust, etc.).

- Produces RDB programs more efficiently than most CAM systems.

Disadvantages:

- G-code requires knowledge of programming language.

- Manual calculations and checks are time consuming

- Numerous calculations increase the probability of a programmer error

- A difficult process that requires the full involvement of the RDB programmer

- Lack of programming staff to implement programs at this level

\section{Programming in the RDB control panel.}

This method involves creating and entering programs directly on the RDB bench control panel using the keyboard and display. In this case, the parameters required for detail processing are entered in the control panel For example, the rotational frequency of the machine spindle, the amount of thrust, the location of the part, the coordinate of the cutting tool, and so on.

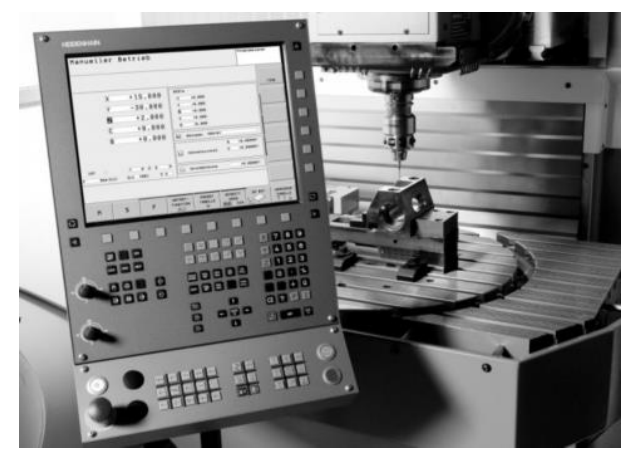

Figure 2. Creating a part machining program using the RDB drilling rig and its control panel.

Advantages

- Easy to learn and simple to use.

- Does not require G-code to write the program.

- Installation and programming times have been reduced

- Fewer software errors.

- More economical than CAM system

\section{Disadvantages}

- Coordinate geometry is limited.

- It is difficult to program for complex and shaped details.

- The cutter does not support the tool shop.

- Does not offer CAM system flexibility.

\section{Programming with CAD / CAM system.}

To succeed in the market today, an industrial enterprise has to work on reducing production time, reducing costs, and improving quality. The rapid development of computer and information technology has led to the emergence of CAD / CAM / CAE systems, which are the most effective means of solving these problems.

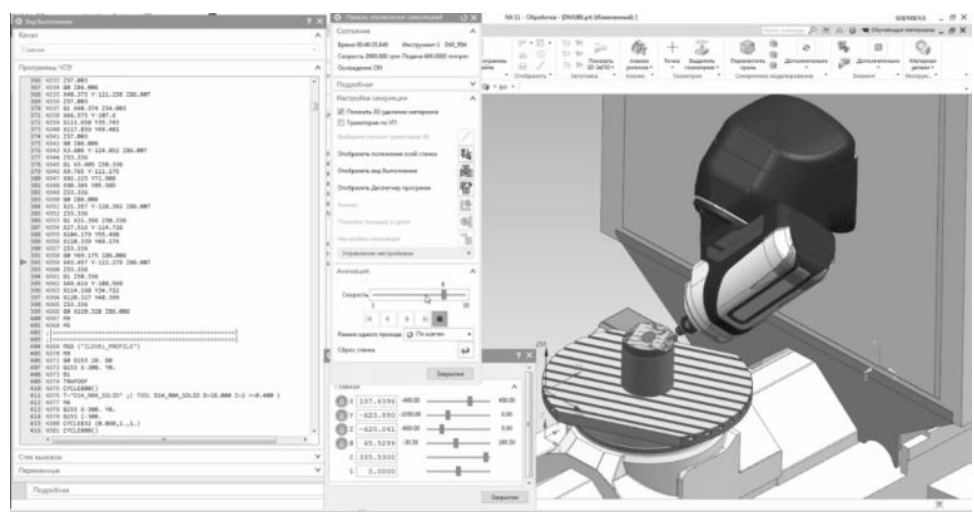

Figure 3. Creating a detail processing program using the CAM system of Siemens NX software. 
CAD systems (computer-aided design) - a software that automates the work of an engineer in the design and allows you to solve problems of product design and technical documentation using a computer.

CAM systems (computer-aided manufacturing) Automate the calculation of the path of cutting tools for processing on RDB machines and provide computeraided management software.

CAE-systems (computer-aided engineering) (computer-assisted engineering calculations) are designed to solve a variety of engineering problems, such as power calculations, thermal process analysis, calculation of hydraulic systems and mechanisms.

\section{Conclusion}

In general, the process of writing a management program in a CAD / CAM system can be expressed in the form of 3 main stages:

The first step is to create a 3D model of the detail and the blank This process is performed by the designerprogrammer in the CAD system;
The second step is the creation of the processing trajectory in the CAM system by the technologist-programmer;

The third step is to deploy and verify the Management Program.

Advantages

- Does not require the programmer to perform mathematical calculations.

- Automates the programming process to increase overall production.

- It is easy to create a program for processing complex and shaped surface details.

- Virtual simulation reduces machine downtime due to software errors.

\section{Disadvantages}

- Effective program management still requires basic knowledge of manual programming.

- Requires software that supports PC and CAD / CAM systems (such as Siemens NX, Catia, Compass 3D).

- Requires the programmer-designer-technologist to be able to work with the above software.

\section{References:}

1. М.С. Аносов, Г.Н. Каневский, Р.Ш. Мансуров, С.Б. Сорокин. Основы разработки управляющих программ для станков с чпу в системе SIEMENS NX. Нижний Новгород 2019.

2. Тешабоев, Анвар Эргашевич, et al. "Машинасозликда юза тозалигини назоратини автоматлаш." Scientific progress 1.5 (2021).

3. Файзимтов, Шухрат Нуманович, and Мухаммадазим Акбаралиевич Рустамов. "Применение прогрессивных методов для ориентации и установки заклепок в отверстие с горизонтальной осью." научный поиск в современном мире. 2017.

4. Файзиматов Ш.Н., and М.А. Рустамов. "Аэродинамический эффект для автоматизации процесса перекачки химических агрессивных реагентов." Современные исследования 6 (2018): 112-115.

5. Рубидинов, Шохрух Ғайратжон Ўғли. "Бикрлиги паст валларга совуқ ишлов бериш усули." Scientific progress 1.6 (2021): 413-417.

6. Todjiboyev R.K., A.A. Ulmasov, and Muxtorov Sh. "3M structural bonding tape 9270." Science and Education 2.4 (2021): 146-149.

7. Тохиров Аъзамжон иброхим угли. «Использование трехмерной графической программы Компас 3D на уроках Черчения в общеобразовательных школах». XXXVI международной научно-практической конференции «Технические науки: проблемы и решения». 